\title{
Spotlight on Arts Education Grantmaking in the San Francisco Bay Area
}

\section{October 2005 / The Foundation Center-San Francisco}

\begin{abstract}
The Foundation Center's mission is to strengthen the nonprofit sector by advancing knowledge about U.S. philanthropy. In conjunction with our Funding for Arts Month in October of 2005, the Foundation CenterSan Francisco is pleased to present this brief picture of arts education grantmaking in the Bay Area.
\end{abstract}

This Spotlight includes side by side comparisons of arts education giving by primary purpose and by target population, illustrating how funding in the Bay Area compares with funding nationally. A mini-directory of selected San Francisco Bay Area foundations making arts education grants in the Bay Area provides basic contact information along with selected grants.

\section{WHY ARTS EDUCATION?}

The arts are central to all civilizations. They provide a means for personal and political expression, for conveying ideas and emotions, and for preserving cultural knowledge from generation to generation. The importance of arts in our society makes the role of those working to pass along an understanding and appreciation of the arts and the skills needed to perpetuate and enhance their many forms especially critical.

Foundations have long supported arts education as a means for building artistic skills and cultivating a life-long appreciation of the arts. They have also recognized that the benefits of arts education go far beyond building audiences and inspiring future artists. In a period of diminished public support for arts education, foundation funding in this area takes on even greater importance.

The Foundation Center, in collaboration with Grantmakers in the Arts, has recently completed a report, Foundation Funding for Arts Education, that documents the size and scope of arts education grantmaking by U.S. foundations. We've included some information from that report here to illustrate how Bay Area giving for arts education compares to the national picture. We hope you find this report informative.

\section{FOUNDATION CENTER GRANTS SAMPLE}

Each year the Foundation Center indexes all of the grants of $\$ 10,000$ and more awarded by roughly 1,000 of the nation's largest independent, corporate, community, and grantmaking operating foundations. Our most recent (2003) sample included more than 120,000 grants awarded by 1,010 U.S. foundations totaling $\$ 14.3$ billion.

Overall, foundations included in the Center's annual grants sample provided more than 3,100 grants totaling $\$ 208.8$ million for arts education on a national basis. Giving in the Bay Area accounted for nearly $7 \%$ of the total. In 2003, the San Francisco Bay Area-including Alameda, Contra Costa, Marin, Napa, Santa Clara, San Francisco, San Mateo, Solano, and Sonoma counties-alone benefited from 240 arts education grants totaling $\$ 14.3$ million. Sixty foundations provided these awards, including 35 Bay Area foundations.

\begin{tabular}{lrc} 
Top Bay Area Funders of Arts Education & $\begin{array}{c}\text { Erts Grant } \\
\text { Dollars }\end{array}$ & $\begin{array}{c}\text { No. of Arts } \\
\text { Grants }\end{array}$ \\
\hline Foundation Name & $\$ 2,315,000$ & 10 \\
1. William and Flora Hewlett Foundation & $1,666,500$ & 8 \\
2. David and Lucile Packard Foundation & $1,280,000$ & 6 \\
3. Baker Street Foundation & $1,014,550$ & 1 \\
4. Jaquelin Hume Foundation & 946,350 & 34 \\
5. The San Francisco Foundation & 616,000 & 22 \\
6. Walter and Elise Haas Fund & 605,000 & 8 \\
7. Wells Fargo Foundation & 510,266 & 18 \\
8. Peninsula Community Foundation & 500,000 & 5 \\
9. James Irvine Foundation & 455,000 & 3 \\
10. Wayne \& Gladys Valley Foundation &
\end{tabular}

Source: Based on all arts education grants to Bay Area organizations of $\$ 10,000$ or more awarded by 35 sampled Bay Area foundations in 2003. 


\section{Mini-Directory}

\section{San Francisco Bay Area Arts Education Funders}

The Baker Street Foundation

135 Main St., Ste. 1140

San Francisco, CA 94105

Description: Funding primarily for education, medical research, human services, and arts and culture.

Selected Grants:

$\$ 150,000$, to San Francisco Jazz Festival for education $\$ 100,000$, to American Conservatory Theater for educational purposes

$\$ 20,000$, to Public Glass for educational programs

\section{William K. Bowes, Jr. Foundation}

2735 Sand Hill Rd.

Menlo Park, CA 94025

Description: Giving primarily for museums, higher education, health care and/or patient services, cancer research, adoption, and religion.

\section{Selected Grants:}

$\$ 80,000$, to San Domenico School for Virtuoso Program

\section{Walter and Elise Haas Fund ${ }^{\wedge *}$}

1 Lombard St., Ste. 305

San Francisco, CA 94111

Web: www.haassr.org

Description: The goal of the arts education program is to increase creative opportunities and interaction with working artists for children and youth who otherwise have limited access to studying the arts.

\section{Selected Grants:}

$\$ 104,000$ over two years to Alameda County Office of Education for activities using arts to engage low-income parents to get involved in their children's educations and expand teacher professional development in the arts

$\$ 15,000$ to Kid Serv Mural Workshop, through which an artist leads children at San Francisco public schools in creating murals on their schools' exterior walls

$\$ 65,000$ over two years to San Francisco Arts Education

Project to strengthen its curriculum serving schools in the San Francisco Unified School District

\author{
The William and Flora Hewlett Foundation ${ }^{\wedge} *$ \\ 2121 Sand Hill Rd. \\ Menlo Park, CA 94025 \\ Web: www.hewlett.org \\ Description: Aims its arts grantmaking at the sustainability \\ of high-quality San Francisco Bay Area organizations by \\ stimulating access to and participation in the arts; \\ increasing exposure to and understanding of diverse \\ cultural expressions; enhancing opportunities for creative \\ expression for both artists and audiences; and promoting \\ long-term organizational health. \\ Selected Grants: \\ $\$ 225,000$ for general support of Young Audiences of \\ Northern California \\ $\$ 250,000$ for Community School of Music and Arts for \\ construction of Center for Music and Arts Education \\ $\$ 115,000$ 3-year grant to the Oakland Youth Chorus for \\ general support
}

\section{The James Irvine Foundation^*}

575 Market St., Ste. 3400

San Francisco, CA 94105

Web: www.irvine.org

Description: The goal of the arts program is to promote a vibrant and inclusive artistic and cultural environment in California. The foundation believes that a healthy arts system must have the ability to create art and connect it to diverse communities, opportunities to explore innovative and risktaking approaches that can help the sector conduct its business more effectively in the future, and well-run arts organizations.

Selected Grants:

$\$ 250,000$ two year grant to East Bay Center for the Performing Arts for core programming activities and for Community Leadership through Arts Study and Service program

$\$ 175,000$ two year grant to San Jose Museum of Art Association for Museum Youth Initiative, to increase academic achievement of middle and high school students through out-of-school educational and youth development opportunities

$\$ 125,000$ to Bay Area Video Coalition to develop interactive digital media training material for underserved students statewide 
Marin Community Foundation^*

5 Hamilton Landing, Ste. 200

Novato, CA 94949

Web: www.marincf.org

Description: Supports opportunities for students and teachers to create, experience, and participate in the rich and diverse world of the arts with emphasis on increasing arts awareness, knowledge, and participation for $\mathrm{K}-12$ students, and promoting collaboration amongst artists and schools.

Selected Grants:

$\$ 80,000$ to Youth in Arts for in-school residencies, youthoriented performances, and program for the developmentally disabled, and to help coordinate arts education providers in Marin county

$\$ 50,000$ to Falkirk Cultural Center to support visual arts education programs in Marin elementary schools

$\$ 24,500$ to California Poets in the Schools for poet-teacher residencies

The David and Lucile Packard Foundation^* 300 2nd St., Ste. 200

Los Altos, CA 94022

Web: www.packard.org

Description: In the area of arts, the foundation's goals are to ensure that local residents utilize the vibrant community of performing and visual arts organizations and see that children actively participate in artistic activities.

Selected Grants:

$\$ 500,000$ to Cultural Initiatives/Silicon Valley for the School

Arts Program/Creative Education Program

$\$ 105,000$ to Community School of Music and the Arts in

Mountain View for core programs and activities

$\$ 25,000$ to San Jose Youth Symphony for core programs and activities

Peninsula Community Foundation^*

1700 S. El Camino Real, Ste. 300

San Mateo, CA 94402-3049

Web: www.pcf.org

Description: The Grants for the Arts program supports

creative excellence, artistic diversity, and youth involvement

in the arts

\section{Selected Grants:}

$\$ 112,000$ to Carlmont High School for Principal's Fund for musical instruments and art studio

$\$ 100,000$ to Redwood City School District for Fine Arts

Program at Fair Oaks Elementary School

$\$ 90,000$ three year grant, to California Art in Action

Foundation to sustain and extend Art in Action

curriculum in the Bay Area and to secure long term funding strategy
The San Francisco Foundation^*

225 Bush St., Ste. 500

San Francisco, CA 94104-4224

Web: www.sff.org

Description: Supports cultural activities in a wide range of disciplines that enhance and encourage individual creativity with emphasis on culturally diverse organizations; programs that promote participation of residents in cultural activities; programs that inspire positive development of children and youth; capacity-building of elementary and secondary schools to enhance the creative and critical reasoning skills of youth; and supporting organizations that promote audiencedevelopment.

Selected Grants:

$\$ 350,000$ to West Contra Costa Unified School District for arts programs

$\$ 100,000$ to Museum of Children's Art for project to provide after-school arts programs throughout West Oakland schools

$\$ 50,000$, to Woodside School Foundation for arts and counseling programs

\section{Wayne and Gladys Valley Foundation^* \\ 1939 Harrison St., Ste. 510 \\ Oakland, CA 94612-3532}

Description: Primary areas of interest include higher, secondary, and other education. The foundation seeks to make grants to organizations having broad based funding support; specifically defined goals and purposes; demonstrated effectiveness in its programs; expectations for continued success in its activities without future dependence on support from the foundation; and committed, enthusiastic and diligent leadership.

Selected Grants:

$\$ 175,000$ to Junior Center of Art and Science for renovation facilities and expansion of programs

$\$ 30,000$ to Oakland East Bay Symphony for education and outreach programs for school year

$\$ 10,000$ to Cantare Con Vivo for Cantare Samaritan Singers after-school music program

The Wells Fargo Foundation^^*

550 California St., 7th FI.

San Francisco, CA 94104

Web: www.wellsfargo.com/donations

Description: Wells Fargo gives priority to requests where the primary purpose of the grant is to benefit people and communities of low and moderate income.

\section{Selected Grants:}

$\$ 50,000$ to Alameda County Office of Education for Arts in Education program

$\$ 50,000$ to Yerba Buena Center for the Arts for Art Tools for Teachers, Artful Adventures, Discovering Performances, School Partnerships, and Young Artists

$\$ 10,000$ to Oakland East Bay Symphony for Music for Excellence program

Source: These foundations have been identified by means of the Foundation Center's 2003 grants sample as having awarded the highest grant dollar amount or greatest number of arts education grants to Bay Area recipients. 


\section{COMPARISONS OF BAY AREA AND NATIONAL GIVING}

\section{Primary Purpose}

Performing arts education and multidisciplinary arts education combined accounted for fully $89 \%$ of all Bay Area giving for arts education, with performing arts capturing the largest share (Figure 1). In a marked departure from the national breakdown of arts education giving, where visual arts accounted for $16 \%$ of the giving, in the Bay Area, visual arts accounted for only $4 \%$. Within performing arts education, music education accounted for the largest share of Bay Area grant dollars, or $33 \%$ of overall arts education giving.

\section{Target Population}

Consistent with national trends, children and youth accounted for the largest share of arts education grant dollars in the Bay Area (Figure 2). College and graduate students represented a much smaller $13.4 \%$ of the total in the Bay Area, as opposed to $17.2 \%$ nationally.

FIGURE 1

\section{Performing Arts Education accounted for the largest share of arts education giving in the Bay Area and nationally in 2003}
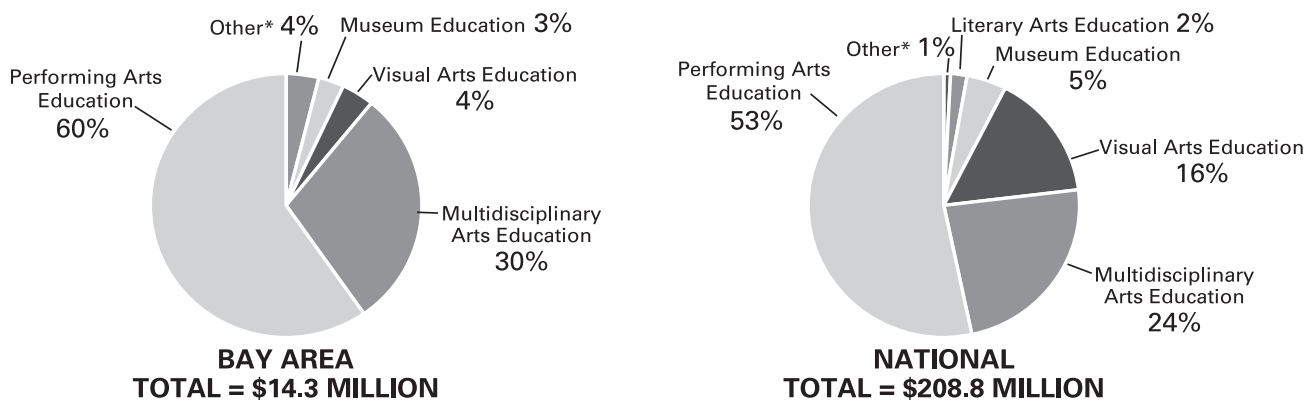

Based on all arts education grants of $\$ 10,000$ or more awarded in 2003 to Bay Area recipients by 60 larger foundations, including 35 Bay Area foundations. Only grants to organizations are included. *Other category represents remaining arts education fields that each account for less that $2 \%$ of total grant dollars.

FIGURE 2

Children and youth accounted for the largest share of arts education grant dollars in the Bay Area and nationally in 2003
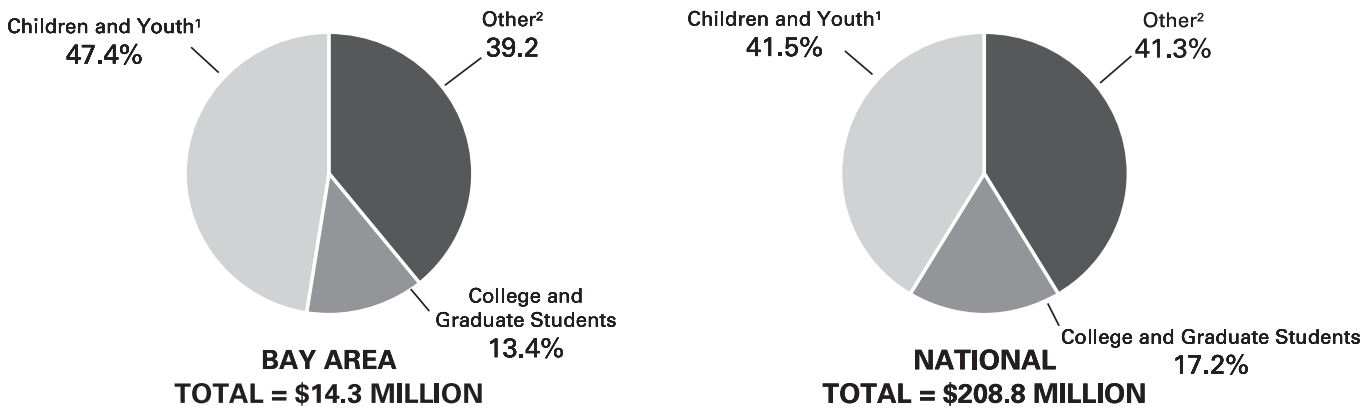

Based on all arts education grants of $\$ 10,000$ or more awarded in the Bay Area in 2003 by 60 larger foundations, including 35 Bay Area foundations. Only grants to organizations are included. ${ }^{1}$ Includes support for in-school and other arts education, including early childhood arts education.

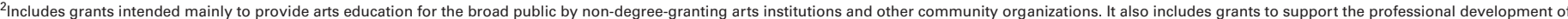
emerging artists and grants lacking sufficient descriptive information to be coded for an age-specific target group.

\section{FOR MORE INFORMATION}

Learn more about arts education grants and grantmaking at the Foundation Center-San Francisco or find a Cooperating Collection near you at www.fdncenter.org/collections. For a broader look at arts education grantmaking see our national report, Foundation Funding for Arts Education, available free at our Web site at www.fdncenter.org/research/trends_analysis.
Funding for this report was provided by:

WALTER \& ELISE HAAS FUND

THE FOUNDATION CENTER-SAN FRANCISCO

312 Sutter St., Suite 606

San Francisco, CA 94108-4323

(415) 397-0902

www.fdncenter.org/sanfrancisco 